\title{
Fundamentos e parâmetros para utilização de medidas executórias atípicas
}

\author{
Fundamentals and parameters for using atypical enforcement measures
}

Nilsiton Rodrigues de Andrade Aragão'

${ }^{1}$ Universidade de Fortaleza - UNIFOR, Brasil

\begin{abstract}
Resumo
O presente artigo analisa as medidas executivas atípicas, com especial enfoque na aplicação do art. 139, IV, do Código de Processo Civil de 2015. É preciso estabelecer parâmetros objetivos claros para orientar as decisões judiciais que estabelecem meios executórios atípicos. A busca de um equilíbrio entre o incremento de efetividade processual e a limitação contra excessos é o que justifica a relevância prática e a atualidade do tema. Para tanto, foi desenvolvida uma pesquisa aplicada e explicativa, realizada por pesquisa bibliográfica e documental, com análise de artigos científicos, doutrina e jurisprudência. Por fim, concluiu-se que a abertura dos meios executórios e o raciocínio adequado das decisões que os determinam são indispensáveis.
\end{abstract}

Palavras-chave: Efetividade processual. Medidas atípicas. Execução. Código de Processo Civil de 2015.

\begin{abstract}
This article analyzes the atypical executive measures, with special focus on the application of art. 139, IV, of the 2015 Code of Civil Procedure. Clear objective parameters need to be established to guide judicial decisions establishing atypical enforceable means. The search for a balance between increasing procedural effectiveness and limiting excesses is what justifies the practical relevance and timeliness of the subject. Therefore, an applied and explanatory research was developed, proceeded by bibliographical and documentary research, with analysis of scientific articles, doctrine and jurisprudence. Finally, it was concluded that the openness of the enforceable means and the adequate reasoning of the decisions determining them are indispensable.
\end{abstract}

Keywords: Procedural effectiveness. Atypical measures. Execution. Procedure Law of 2015.

\section{Introdução}

A tutela jurisdicional executiva vem ganhando cada vez mais relevo quando se analisa a garantia fundamental à inafastabilidade da jurisdição sob a perspectiva da efetividade. É por intermédio dela que se altera a realidade jurídica para impor a satisfação da obrigação juridicamente reconhecida, é por esse provimento jurisdicional que se realiza o acesso à justiça de forma conclusiva. ${ }^{1}$ É por meio da execução que se materializa o "dever ser" da norma jurídica no mundo empírico. Aí está a razão da célebre metáfora segundo a qual, ao passo que o processo de conhecimento transforma o fato em direito, o processo de execução transforma o direito em fato. ${ }^{2}$ Logicamente, esse último fato será

$1 \quad$ Araken de Assis conceitua a execução nos seguintes termos: "Tem o ato executivo de peculiar, distinguindo-o, destarte, dos demais atos do processo e dos que do juiz se originaram, a virtualidade de provocar alterações no mundo natural. Objetiva a execução, através de atos desse jaez, adequar o mundo físico ao projeto sentencial” (ASSIS, 2016, p. 130). 2 ASSIS, 2016, p. 107. 
substancialmente distinto do primeiro, exatamente por representar uma adequação da realidade aos preceitos jurídicos.

A preocupação com o papel da execução na efetividade da prestação jurisdicional tem sido um dos aspectos primordiais da política judiciária brasileira dos últimos anos. Os dados estatísticos da litigiosidade nacional demonstram o impacto negativo da ineficiência das execuções que, sem resolução definitiva, se acumulam e são responsáveis pelas mais altas taxas de congestionamento processual.

Na busca constante de soluções para o problema, os olhos da doutrina têm se voltado para o fortalecimento e expansão dos meios executórios. Necessário se faz necessária a criação e a utilização de ferramentas que possibilitem ao Magistrado a efetivação de suas decisões.

O Código de Processo Civil vigente prevê zonas de maior capacidade de adequação às exigências de cada caso concreto. A maleabilidade procedimental e o compartilhamento de técnicas entre procedimentos são a tônica do sistema processual vigente, potencializado por institutos dispostos de forma aberta, como, por exemplo, a atipicidade de meios de solução de conflitos (art. 3. ${ }^{\text {) }}$, A atipicidade dos meios de cooperação judiciária (arts. 67 a 69), a atipicidade dos meios executórios (art. 139, IV), a atipicidade dos negócios processuais (art. 190) e a atipicidade dos meios de prova (art. 369).

No recorte epistemológico proposto, a atenção será dada à atipicidade dos meios executórios com o intuito de avaliar seu potencial de contribuir para a superação dos gargalos da execução jurisdicional. Assim, faz-se necessário, por meio de pesquisa bibliográfica e jurisdicional utilizando do método indutivo, abordar os critérios e limites para aplicação das referidas medidas, bem como trazer as reflexões e parâmetros que vem sendo apontados como necessários à correta aplicação desse instituto.

\section{A busca da efetividade processual}

Uma das dimensões do princípio da inafastabilidade da jurisdição é a realização concreta do direito reconhecido pelo Judiciário, ou seja, a efetividade da prestação jurisdicional. Para ser efetivo o processo deve realizar de forma célere, completa e correta o direito material no qual se fundamenta o litígio. No entanto, com muita frequência, se percebe uma dificuldade de concretizar no mundo dos fatos os direitos reconhecidos em títulos executivos judiciais e extrajudiciais. Nessa linha, o princípio da efetividade processual proclama como valor base a imprescindibilidade dessa satisfação.

Essa efetividade é almejada pelo atual Código de Processo Civil de forma veemente, tendo a matéria se apresentado como uma das premissas orientadoras do sistema processual moderno. ${ }^{3}$ Somente um ordenamento que proporcione a realização concreta dos direitos violados harmoniza-se integralmente com as garantias constitucionais de um Estado Democrático de Direito. ${ }^{4}$

O pensamento do processo como garantia não pode ser fundamento para sua ineficácia, pois ele é garantia para ambas as partes. A defesa do devedor deve ser voltada contra execuções indevidas e não contra toda e qualquer execução. O direito de propriedade do devedor deve ser analisado conjuntamente com o direito do credor, pois a frustração de um crédito é tão ofensiva à ordem jurídica quanto uma

3 De acordo com a exposição de motivos do então anteprojeto do código processual civil: "Um sistema processual civil que não proporcione à sociedade o reconhecimento e a realização dos direitos, ameaçados ou violados, que têm cada um dos jurisdicionados, não se harmoniza com as garantias constitucionais de um Estado Democrático de Direito. Sendo ineficiente o sistema processual, todo o ordenamento jurídico passa a carecer de real efetividade. De fato, as normas de direito material se transformam em pura ilusão, sem a garantia de sua correlata realização, no mundo empírico, por meio do processo" (Disponível em: https://www.senado.gov.br/senado/novocpc/pdf/Anteprojeto.pdf).

$4 \quad$ Nas lições de Barbosa Moreira: "Querer que o processo seja efetivo é querer que desempenhe com eficiência o papel que lhe compete na economia do ordenamento jurídico. Visto que esse papel é instrumental em relação ao direito substantivo, também se costuma falar da instrumentalidade do processo. Uma noção conecta-se com a outra e por assim dizer a implica. Qualquer instrumento será bom na medida em que sirva de modo prestimoso à consecução dos fins da obra a que se ordena; em outras palavras, na medida em que seja efetivo. Vale dizer: será efetivo o processo que constitua instrumento eficiente de realização do direito material” (MOREIRA, 2002, p. 181). 
expropriação indevida. Por essa razão, o sistema de proteção do devedor não pode ensejar a inefetividade da execução. ${ }^{5}$

A base fundamental do princípio da efetividade processual está no princípio constitucional da inafastabilidade da jurisdição (art. 5. ${ }^{\circ}, \mathrm{XXXV}$, da CF/1988), na concepção de que tal norma não se limita a resguardar o mero direito ao peticionamento, mas abriga, também, a garantia do acesso à ordem jurídica justa por meio de uma prestação jurisdicional efetiva. ${ }^{6}$

O reconhecimento dessa base constitucional ao princípio da efetividade é essencial para que se perceba a natureza fundamental do direito à satisfação dos créditos. ${ }^{7}$ Esse status normativo é necessário para viabilizar a solução de questões complexas da execução jurisdicional que precisam ser tratadas no nível de colisão de princípios constitucionais. Algumas intervenções e meios executórios invadem área do patrimônio jurídico do executado que, em princípio, poderiam ser consideradas violadoras de garantias constitucionais do devedor, mas tornam-se legitimas por preponderar no caso concreto o direito ao acesso à justiça em sua dimensão de efetividade jurisdicional.

A efetividade processual ganhou manifestação normativa infraconstitucional expressa nos artigos 4.ํㅜ e 6. do CPC, no qual também estão previstos os princípios da razoável duração do processo e da primazia da tutela de mérito. Convém destacar que a ausência de um dispositivo normativo exclusivo não compromete sua autonomia. Os princípios jurídicos, por natureza, possuem um elevado âmbito de aplicabilidade, muitas vezes coincidente com o de outros princípios, razão pela qual, é comum que se adote a técnica legislativa de disciplinar vários direitos correlatos em um único dispositivo normativo.

Assim, sem questionar a indubitável relação que possui com outras normas de base valorativa convergente, é possível sustentar a autonomia normativa da efetividade processual, uma vez que detém núcleo essencial próprio bem definido, principalmente quando é analisado sob a perspectiva da jurisdição executiva.

A efetividade processual se manifesta de forma prática em diversos aspectos ${ }^{8}$, entre os mais importantes, destaca-se a utilização dos meios executórios necessários à satisfação do crédito, inclusive por medidas atípicas. Respeitando recorte proposto para o presente estudo, passa-se a analisar essa dimensão da efetividade processual de forma mais específica.

\section{O poder geral de efetivação}

O Poder Judiciário não pode deixar de efetivar prestação reconhecida em um título executivo sob o fundamento de não ser capaz de superar a resistência do devedor. ${ }^{9}$ Nesses estudos, a abrangência do princípio da atipicidade dos meios executórios está entre os temas de maior relevância prática.

5 Em uma análise da raiz histórica dessa distorção, Hermes Zaneti Jr. destaca: "a distorção resultou em uma distorção em benefício do devedor segundo a qual, pela gravidade da invasão do direito de propriedade, apenas um procedimento complexo para a expropriação, com muitas garantias para o executado, poderia estar de acordo com o processo justo" (ZANETI JR, 2016, p. 49).

6 "Nesse sentido, o direito à sentença deve ser visto como direito ao provimento e aos meios executivos capazes de dar efetividade ao direito substancial, o que significa direito à efetividade em sentido estrito" (MARINONI, 2010, p. 139).

7 De acordo com Marcelo Lima Guerra esse direito fundamental consiste "na existência de um sistema completo de tutela executiva, no qual existia meios executivos capazes de proporcionar pronta e integral satisfação a qualquer direito merecedor de tutela executiva" (GUERRA, 2003, p. 102).

8 Marcelo Lima Guerra estabelece três orientações interpretativas para garantir a efetividade processual: “a) O juiz tem o poder-dever de interpretar as normas relativas aos meios executivos de forma a extrair delas um significado que assegure a maior proteção e efetividade ao direito fundamental à tutela executiva; b) o juiz tem o poder-dever de deixar de aplicar normas que imponham uma restrição a um meio executivo, sempre que tal restrição - a qual melhor caracteriza-se, insista-se, uma restrição ao direito fundamental à tutela executiva - não for justificável pela proteção devida a outro direito fundamental, que venha a prevalecer, no caso concreto, sobre o direito fundamental à tutela executiva; c) o juiz tem o poderdever de adotar os meios executivos que se revelem necessários à prestação integral de tutela executiva, mesmo que não previstos em lei, e ainda que expressamente vedados em lei, desde que observados os limites impostos por eventuais direitos fundamentais colidentes àquele relativo aos meios executivos” (GUERRA, 2003, p. 103-104).

9 Em sua tese de doutorado, Marcos Youji Minami defende: "A vedação ao non liquet gera uma consequência lógica. Em regra, não se pode permitir que o judiciário deixe de efetivar prestação certificada em uma decisão ou em um título 
A complexidade das relações processuais, em especial das de cunho executório exige que sejam dadas respostas mais rápidas e específicas para fazer frente aos variados e imprevisíveis obstáculos que se apresentam. ${ }^{10}$ Por conseguinte, um disciplinamento normativo mais aberto da atividade executória confere maior capacidade de adequação processual às necessidades do caso concreto.

Peculiaridades da causa podem demonstrar a omissão do Código ou a inefetividade dos mecanismos processuais expressamente previstos, exigindo que o juiz utilize outras medidas que se apresentem mais apropriadas para a hipótese, ainda que sem disciplinamento legal. Sob esse fundamento, o Código possui dispositivos normativos que estabelecem a atipicidade dos meios executórios destinados a regular áreas específicas do processo, como é o caso dos artigos 297, 390, parágrafo único, 400, parágrafo único, 403, parágrafo único, 536 e 773 do CPC. Todavia, o artigo 139, IV, do CPC trata a atipicidade de forma ampla e abstrata, com o intuito de estabelecer um poder geral de efetivação.

Compreende-se por atipicidade dos meios executórios, em apertada síntese, a autorização legal para que o magistrado determine medidas executórias não previstas expressamente na legislação. E preciso compreender que a atipicidade dos meios executórios não é uma inovação trazida pelo CPC/2015, ela já era uma realidade no âmbito das execuções de obrigações não pecuniárias antes do novo Código. A mudança está principalmente no artigo 139, IV, do CPC, embora não se restrinja a ele (arts. 297 e 536 do CPC). Esse dispositivo além de tratar da atipicidade na Parte Geral do Código, o que já estende a amplitude de sua incidência, também fez referência expressa às ações que tenham por objeto prestação pecuniária.

A base desse instituto está nas formas de execução. Como se sabe, para dar início à execução, parte-se do pressuposto de que a crise jurídica que ensejou o inadimplemento decorre do fato de a vontade do executado estar em desacordo com a lei, ou seja, ele não pretende adimplir o seu débito. Nesse contexto, exige-se a intervenção do Estado, na condição de responsável pela garantia da paz social, para atuar no sentido de substituir ou de induzir a vontade do executado, o que pode ocorrer, em síntese, por subrogação ou por coerção.

A primeira forma de efetivação das medidas executórias é a que se realiza por sub-rogação, consistente no conjunto de medidas pelas quais o Estado substitui a vontade do executado, agindo independentemente de sua colaboração, para viabilizar o cumprimento da obrigação executada. O magistrado, subrogando-se na posição do devedor da prestação, adota as medidas que deveriam ter sido tomadas por ele. São exemplos de medidas sub-rogatórias típicas: a apreensão de bens, a alienação, a adjudicação, a apropriação de frutos e rendimentos de empresa ou de estabelecimentos e de outros bens, o desconto em folha de pagamento, etc.

A segunda forma de efetivação das medidas executórias é a que se realiza por coerção, consistindo no conjunto de medidas de pressão psicológica sobre o executado para que ele próprio cumpra a obrigação de forma voluntária, embora não espontânea. A medida destina-se a induzir a vontade do executado, adequando-a às disposições legais. Podem-se citar como exemplo as medidas coercitivas típicas que têm por objeto o patrimônio, como é o caso das astreintes, ou outras que visam o próprio executado, na hipótese excepcional da prisão civil do devedor de alimentos.

Também podem ser incluídos no âmbito dos mecanismos de execução indireta instrumentos processuais de incentivo, ou seja, que tragam um benefício ao devedor. É o que ocorre com a isenção de custas, quando do cumprimento do mandado monitório (art. 701, § 1., do CPC), e com a redução dos honorários advocatícios, quando do pagamento tempestivo da obrigação pecuniária (art. 827, § 1.․․ do CPC).

executivo extrajudicial com a justificativa de não ser possível essa realização - o que aqui se batize de vedação ao non factibile. Proibir o non liquet, mas permitir o non factibile seria uma contradição. É preciso evitar o non factibile como decorrência do devido processo legal e da própria razão de criação do judiciário. Nesse aspecto, mesmo havendo mecanismos para impedir o non liquet, se o comando do dispositivo não se concretizar por ausência de técnica executiva, poderá ocorrer, ainda assim, vedação ao acesso à Justiça”. (MINAMI, 2019, p. 295-296).

10 Enunciado n.o 48 da Enfam: "O art. 139, IV, do CPC/2015 traduz um poder geral de efetivação, permitindo a aplicação de medidas atípicas para garantir o cumprimento de qualquer ordem judicial, inclusive no âmbito do cumprimento de sentença e no processo de execução baseado em títulos extrajudiciais”. 
Cumpre registrar que a execução indireta já sofreu restrições diante da defesa de uma pretensa intangibilidade da vontade humana, mas hoje, de acordo com a concepção moderna do processo civil, concebe-se inclusive certa predominância dos meios coercitivos, por se mostrarem mais eficazes e menos dispendiosos em muitos casos.

É importante mencionar que o Código faz referência a outras formas de execução, constando no rol do artigo 139, IV, do CPC menção a medidas indutivas e mandamentais, além das citadas medidas coercitivas e sub-rogatórias. No contexto geral, essas duas outras formas de execução podem ser compreendidas no âmbito conceitual das medidas coercitivas, apenas com abordagens mais específicas.

Não há uma uniformidade absoluta na distinção conceitual dessas formas de execução. As medidas mandamentais são comumente designadas como aquelas dirigidas ao cumprimento da obrigação pelo próprio executado ou de uma técnica decisória na qual o pronunciamento judicial de uma só vez reconhece o direito e determina seu cumprimento. A as indutivas, por sua vez, podem ser relacionadas à indução por meio de benefícios ou privilégios, ações que tragam vantagens ao devedor se houver o cumprimento da obrigação de forma espontânea.

O tecnicismo conceitual nesse ponto perde importância diante da identidade de regime jurídico entre elas. A finalidade do Código, ao mencionar toda a variedade de meios executórios, foi ampliar a atuação executória e não a restringir.

\section{Perspectivas do alcance do poder geral de efetivação}

O alcance dos efeitos práticos desse dispositivo divide opiniões. Sem pretensão reducionista da riqueza de percepções que o tema permite, para fins didáticos é possível agrupar as principais posições doutrinárias em três grupos.

Uma primeira corrente nega aplicabilidade à atipicidade dos meios executórios. O fundamento central desse pensamento está nas garantias do devido processo legal. Com o intuito de resguardar aos executados maior previsibilidade e segurança nos processos de execução, diversos meios executórios encontram-se tipificados na legislação. O extenso rol dessas ferramentas processuais disciplinadas no Código e a necessidade de uma observância mais segura do devido processo legal indicam para os adeptos desse pensamento a incompatibilidade constitucional da atipicidade executória. ${ }^{11}$ A atuação jurisdicional ficaria limitada, portanto, às medidas expressamente disciplinadas no CPC.

No extremo oposto das discussões estão aqueles que entendem que a atipicidade dos meios executórios possibilita uma desconsideração de qualquer regra posta sobre a execução, permitindo uma adequação processual quase irrestrita no âmbito das execuções. Assim, em prol da efetividade, seria possível ignoras inclusive técnicas processuais disciplinadas, aplicando-se um sistema de técnica executiva maleável. ${ }^{12}$

A posição intermediária, adotada pela maior parte da doutrina e com a qual nos associamos, entende que a atipicidade se manifesta a partir da constatação de ineficácia ou insuficiência dos dispositivos típicos, por serem eles fruto de uma evolução histórica atenta às exigências que se apresentaram com o tempo. Por mais que os procedimentos executórios possuam um disciplinamento normativo mais aberto, conferindo maior área de atuação jurisdicional com o intuito de viabilizar uma adequação dos meios executórios às necessidades do caso concreto, essa maleabilidade dos atos executórios não importa em

11 Assim compreende Araken de Assis, como se extrai do seguinte excerto: "O direito brasileiro consagra o princípio da tipicidade dos meios executórios. Não pode ser diferente, porque a CF / 1988 tem feição garantista e o art. 5.․․, LIV, exige que a privação de bens obedeça ao devido processo legal. A ideia da relativa atipicidade, defendida com base na regra equivalente ao atual art. 536, § 1.․, esbarra na falta de exemplos práticos convincentes e, ainda, nos valores consagrados na CF/1988" (ASSIS, 2016, p. 186).

12 Destacam Luiz Guilherme Marinoni, Sérgio Cruz Arenhart, Daniel Mitidiero: “Trata-se de regra que visa à promoção da tutela específica dos direitos, pugnada pela doutrina preocupada com a efetividade do processo. Com isso, o direito brasileiro afasta-se de um sistema de técnica executiva rígida e avizinha-se a um sistema de técnica executiva maleável, seguindo nesse particular tendência que emerge do direito comparado. Todos os meios processuais têm de estar disponíveis para a tutela dos direitos" (MARINONI; ARENHART; MITIDIERO, 2017, p. 392). 
uma liberdade discricionária do magistrado. Por conseguinte, a utilização de meios executórios atípicos exige a observância de critérios objetivos. ${ }^{13}$

Logicamente, para as obrigações de fazer, não fazer e entregar coisa, a atipicidade é a regra, manifestada na regulamentação mais sucinta e aberta do procedimento. Já na execução por quantia, existe uma expressiva regulamentação da penhora e expropriação dos bens que não pode ser simplesmente desconsiderada.

Um aspecto que merece destaque na definição desse poder é o fato de que as medidas são executórias e, portanto, não abrangem medidas punitivas, de modo que não é possível utilizar o artigo 139, IV, do CPC para fundamentar a imposição de multas sancionatórias sem previsão expressa.

Ao disciplinar o poder geral de efetivação, o artigo 139, IV, do CPC não define de forma expressa a destinação das ordens. Independentemente do regramento específico, é fácil concluir que as partes do processo são destinatários naturais das medidas executórias atípicas, em especial por eles já estarem inseridos no contraditório. $\mathrm{O}$ aspecto que pode gerar questionamento nessa questão é a destinação dessas medidas a terceiros.

Para compreendê-la, é necessário distinguir duas situações de sujeitos que podem ser atingidos e que não são partes do processo. O primeiro grupo que pode ser atingido pelos atos executórios é formado por aqueles para os quais se dirige a ordem judicial, como, por exemplo, o Serasa, na retirada do nome do devedor de seus cadastros, ou um cartório de registros, na exclusão de uma averbação no registro de um imóvel.

Um segundo grupo de terceiros, para os quais não se dirigiu a ordem judicial, não pode ser destinatário das medidas executórias. Assim, por exemplo, não é possível reter o passaporte da esposa do devedor com a finalidade de coagir o devedor ao cumprimento da obrigação.

\section{Requisitos para deferimento de medidas executórias atípicas}

Há uma premissa que deve ser destacada antes de se elencar os requisitos: a fundamentação da decisão que determina a medida atípica. O pronunciamento do juiz relacionado a esse ato possui cunho decisório e, portanto, deve necessariamente estar fundamentado, atendendo aos requisitos dispostos no artigo 489, § 1.․ do CPC. Na verdade, a ausência de um substrato legal específico que discipline o cabimento e a forma de aplicação do meio executório atípico elevam a complexidade da fundamentação, pois delega ao juiz a realização desse detalhamento por ocasião da decisão.

Essa fundamentação deve contemplar as razões da escolha da medida específica eleita para o caso em questão, atendendo a particularidades da situação concreta em análise. ${ }^{14}$ Uma fundamentação genérica que se limite a dispor sobre a necessidade de satisfação da obrigação, a qual se prestaria a justificar qualquer outra decisão, não é suficiente.

Seguindo a trilha das incursões doutrinárias que já desbravaram uma área importante do fértil e espinhoso terreno dos meios executórios atípicos, é possível destacar pelo menos quatro requisitos

13 A Terceira turma do STJ já decidiu, por exemplo, que “ [...] A interpretação sistemática do ordenamento jurídico revela, todavia, que tal previsão legal não autoriza a adoção indiscriminada de qualquer medida executiva, independentemente de balizas ou meios de controle efetivos. De acordo com o entendimento do STJ, as modernas regras de processo, ainda respaldadas pela busca da efetividade jurisdicional, em nenhuma circunstância poderão se distanciar dos ditames constitucionais, apenas sendo possível a implementação de comandos não discricionários ou que restrinjam direitos individuais de forma razoável. [...] A adoção de meios executivos atípicos é cabível desde que, verificando-se a existência de indícios de que o devedor possua patrimônio expropriável, tais medidas sejam adotadas de modo subsidiário, por meio de decisão que contenha fundamentação adequada às especificidades da hipótese concreta, com observância do contraditório substancial e do postulado da proporcionalidade”. (REsp 1788950/MT, Rel. Ministra NANCY ANDRIGHI, TERCEIRA TURMA, julgado em 23/04/2019, DJe 26/04/2019).

14 Sobre a fundamentação, explica Marcos Youji Minami: "Não apenas credor e devedor (ou responsável), mas o titular do poder Politico precisa saber as razões que levaram o juiz a escolher determinada medida e como ela deve ser instrumentalizada. [...] Nesse sentido, a fundamentação da decisão terá ainda maior relevo e, quanto mais grave for a medida de coerção ou sub-rogação imposta, maior deve ser a justificativa de seu emprego" (MINAMI, 2015, p. 226). 
cumulativos que devem ser observados para que se faça uso desses mecanismos: I) subsidiariedade em relação aos meios executórios típicos; II) possibilidade de cumprimento da prestação pelo destinatário da ordem; III) indispensabilidade da submissão do meio executório atípico indicado pelo juiz ao contraditório; IV) proporcionalidade da medida atípica. ${ }^{15}$ Como se percebe, esses requisitos estabelecem a estrutura da fundamentação que o juiz deverá apresentar para aplicar a medida executória, eles dão base à motivação da decisão.

Esses quatro requisitos são, logicamente, exemplificativos, de modo que outros requisitos podem mostrar-se necessários no caso concreto. No entanto, não se deve vincular a atuação do juiz a um número demasiadamente elevado de requisitos, sob pena de criar-se um sistema muito rígido, que inviabilize a aplicação prática do dispositivo.

Quanto ao primeiro requisito apontado, importa dizer que não se mostra razoável simplesmente ignorar as medidas típicas quando da definição dos atos executórios no caso concreto. A previsão legal e a regulamentação mais detalhada da forma de efetivação desses meios executórios garantem maior segurança na condução do processo, razão pela qual devem eles ser priorizados.

Dessa forma, as medidas atípicas, quando mais gravosas, só devem ser aplicadas de forma suplementar às medidas típicas. ${ }^{16}$ Cabe ao juiz primeiramente avaliar as medidas previstas no Código e determinar aquela que se apresente adequada. Caso a medida inicialmente determinada não atinja seu desiderato, o Estado não pode ficar inerte, devendo o juiz utilizar os meios necessários ainda que não previstos na Lei.

A subsidiariedade não deve implicar no exaurimento prático de todas as medidas típicas em tese cabíveis. É possível, de forma excepcional, utilizar primeiramente uma medida atípica se houver fundamento consistente para concluir previamente pela absoluta inefetividade dos meios típicos. Assim, o juiz pode justificar a dispensa dos meios típicos, embora isso demande maior esforço argumentativo para justificar a postura. É o caso, por exemplo, de um devedor multiexecutado do qual já se tem notícia da inexistência de bens penhoráveis pelo esgotamento das diligências em outro processo, em tal situação não se mostra razoável determinar diligências já realizadas em outros casos para definir a ineficiência da penhora.

Como se percebe, a subsidiariedade não provoca uma restrição exacerbada da atipicidade dos meios executórios, apenas impõe uma utilização mais racional dessa técnica. É necessário ter em mente que os meios executórios típicos, em regra, guardam uma correlação intrínseca com o objeto da execução à qual se destinam e que seus limites e consequências jurídicas estão previamente determinados na lei. A ausência dessas características nos meios executórios atípicos impõe uma maior cautela em sua utilização.

A subsidiariedade dos meios executórios atípicos não é absoluta, uma vez que é possível a utilização de medidas executivas atípicas que se apresentem menos gravosas e igualmente eficazes no caso concreto. É uma premissa equivocada entender que os meios executórios atípicos traduzem uma situação mais gravosa ao executado em todas as suas manifestações.

É possível a utilização do artigo 139, IV, em favor do devedor, sem prejudicar a atividade executiva nem a entrega da prestação jurisdicional devida. É o que ocorre, por exemplo, na utilização de um meio executório atípico em uma execução de alimentos na qual se pretende a prisão civil do devedor ou no caso de penhora de imóvel residencial do fiador. Destaque-se que, em tais casos, incumbe ao executado, quando se insurgir contra uma medida executiva atípica, o ônus de apontar a existência de outro meio menos gravoso e igualmente eficaz, na forma do artigo 805 do CPC.

15 Enunciado n. ${ }^{\circ} 12$ do FPPC: "A aplicação das medidas atípicas sub-rogatórias e coercitivas é cabível em qualquer obrigação no cumprimento de sentença ou execução de título executivo extrajudicial. Essas medidas, contudo, serão aplicadas de forma subsidiária às medidas tipificadas, com observação do contraditório, ainda que diferido, e por meio de decisão à luz do art. 489, § 1.․․ I e II”.

16 Marcus Vinícius Motter Borges defende que "para a aplicação das medidas coercitivas atípicas, mostra-se indispensável o esgotamento das tentativas de penhora e expropriação, bem como o precedente uso das coerções típicas consubstanciadas no protesto da decisão judicial e na inscrição do devedor nos cadastros de inadimplentes”. (BORGES, 2019, p. 358). 
O segundo requisito indicado cinge-se à possibilidade de cumprimento da prestação pelo destinatário da ordem. O inadimplemento da prestação deve ser relativo, voluntário e inescusável, ou seja, o não cumprimento da obrigação deve decorrer unicamente da recalcitrância do devedor. Assim, por exemplo, no âmbito de meios coercitivos, deve estar evidenciado no caso concreto que a pressão volitiva ou força sub-rogatória do meio executório é capaz de conduzir ao cumprimento da obrigação devida.

Se a obrigação não for passível de cumprimento, o meio executório apresentar-se-á como verdadeira punição, o que não é admissível. ${ }^{17}$ Ela não se destina a punir o executado por ato ilegal, mas a restaurar uma situação de inadimplemento, objetivando o restabelecimento, o mais próximo possível, do status quo ante. Em respeito aos princípios orientadores da execução cível, como o da responsabilidade patrimonial e o da menor onerosidade, qualquer desvirtuamento da atividade executória que a direcione para uma noção punitiva deve ser prontamente corrigido.

Para tanto, deve o executado apresentar justificativa da impossibilidade do cumprimento da obrigação, uma vez que na grande maioria das vezes tal informação não constará dos autos do processo, dificultando seu conhecimento pelo julgador.

O terceiro requisito é a indispensabilidade da submissão do meio executório atípico ao contraditório. O diálogo com as partes é muito importante para um correto dimensionamento do meio executório a ser utilizado, pois estas podem trazer aos autos elementos da demanda até então desconhecidos, mas relevantes para definição da melhor forma de execução.

A determinação do meio executório é uma atribuição do juiz, podendo, na maioria dos casos, ser determinada inclusive de ofício (art. 782 do CPC). Somente quando a lei dispõe expressamente de modo diverso, fica a determinação da medida executória condicionada ao requerimento do exequente, como ocorre com a penhora de dinheiro em depósito ou em aplicação financeira (art. 854 do CPC), prisão civil do devedor de alimentos (art. 528 do CPC) e a inclusão do nome do executado em cadastros de inadimplentes (art. 782, § 3oㅡ, do CPC). Essa mesma regra é aplicável ao meios executórios atípicos, ou seja, não havendo tratamento legal, não ficam condicionados à requerimento do exequente, ainda que o pedido possa simplificar a situação no caso concreto. Registre-se que existe entendimento em sentido contrário. ${ }^{18}$

A possibilidade de determinação de ofício de um meio executório pelo juiz não afasta a necessidade de ouvir o executado sobre a matéria. O CPC tem como um de seus pilares o respeito às garantias constitucionais, razão pela qual não parece razoável que a primeira notícia que o executado ou um terceiro tenha sobre a execução seja a efetivação de uma penhora ou de outro ato executório. Somente quando efetivamente necessário, deve-se praticar um ato executório antes de ouvir a parte que será por ele atingida.

Assim, tanto com fundamento na cooperação como no contraditório, impõe-se que as partes sejam ouvidas e possam influir concretamente na definição da medida que será utilizada. Mesmo que o juiz já tenha indicado o meio executório, as partes podem ponderar sobre a sua adequação ao caso ou mesmo propor outras medidas que possam apresentar-se mais eficientes ou menos onerosas.

Logicamente, alguns atos executórios têm sua eficácia reduzida ou prejudicada se o executado tiver ciência antecipada de sua determinação. Isso não obsta o contraditório, apenas orienta que a manifestação do executado seja postergada para um momento futuro. Em tais hipóteses, é importante que a medida seja reversível, evitando-se, assim, que o contraditório diferido seja realizado como uma mera formalidade.

17 Embora tenha restrições à utilização da prisão civil como medida atípica, leciona Daniel Amorim Assumpção Neves sobre essa restrição: "Dessa forma, a adoção de qualquer medida executiva, as atípicas especialmente, deve ser amparada em indícios presentes no processo de que a pressão psicológica por elas exercidas pode efetivamente funcionar para se obter no caso concreto a satisfação do direito exequendo. [...]. Em outras palavras, a adoção de medidas atípicas, em especial de natureza coercitiva, previstas no art. 139, IV, do Novo CPC, deve ser dirigida ao devedor que não paga porque não quer e não para aquele que não paga porque não pode" (NEVES, 2017, p. 126).

18 Em sentido contrário, Marcus Vinícius Motter Borges sustenta que "para o emprego das medidas coercitivas atípicas, mostra-se indispensável o requerimento expresso da parte, sendo inviável a atuação de ofício do juiz”. (BORGES, 2019, p. 359). 
Por fim, impõe-se analisar a proporcionalidade da medida, mais especificamente, se esta é necessária, adequação e proporcional para o caso. O julgador deve motivar a pertinência e a necessidade do meio executório atípico eleito, enfrentando os argumentos deduzidos pelas partes. A necessidade já foi em parte enfrentada por ocasião do estudo da subsidiariedade, uma vez que a medida atípica é necessária por não terem sido frutífera as típicas.

Os meios executórios atípicos devem ser adequados, ou seja, precisam guardar uma coerência com o propósito a ser atingido, com a obrigação perseguida e com a resistência apresentada pelo executado. A utilização de medidas atípicas desconectas da realidade da causa, eleitas de forma aleatória, pode assumir feições de punição, deturpando a finalidade executória do instituto.

Todavia, a exigência de relação entre a medida executória e a prestação devida não pode ser levada ao extremo, sob pena de inviabilizar sua utilização. Não se trata propriamente de uma correlação com a prestação devida, isso só ocorre nos meios executórios de natureza sub-rogatória. Nos coercitivos, a busca é pelo meio executório que garanta a alteração do convencimento do devedor, não há como exigir uma correlação com o objeto da execução. ${ }^{19}$

Assim, por exemplo, se a retenção da habilitação para dirigir ficar restrita unicamente às obrigações diretamente relacionadas ao ato de dirigir, como o inadimplemento de multas de trânsito ou a responsabilidade civil por acidentes de trânsito, seu âmbito de incidência ficará demasiadamente restrito. ${ }^{20}$ Essa postura limita o potencial que os meios executórios atípicos possuem para satisfação de obrigações de natureza variada.

Tais meios executórios devem também atender a uma proporcionalidade em sentido estrito, no sentido de que não podem ser utilizados por puro arbítrio, com excesso, com a adoção de medidas mais drásticas em detrimento de outras igualmente eficazes e menos onerosos ou contundentes. É preciso definir a medida executória com equilíbrio e razoabilidade. A desproporcionalidade fere a própria função executória própria do poder geral de efetivação previsto no CPC.

\section{Alguns exemplos de medidas executórias atípicas}

Como já apresentado, os mecanismos executórios tipicamente previstos no Código não exaurem as possibilidades de atuação executória do magistrado, resta definir, porém, quais sejam as demais medidas executórias atípicas que podem ser utilizadas. Exatamente por serem atípicas não é tarefa fácil estabelecer uma lista definitiva com as possibilidades aceitas, sendo certo que sempre haverá uma discussão sobre o cabimento.

Dentre as medidas já utilizadas na prática ou defendidas pela doutrina, destaca-se, como exemplo, o bloqueio de verbas públicas para viabilizar o fornecimento de medicamentos, entendimento já firmado pelo STJ no rito dos recursos especiais repetitivos. ${ }^{21}$ Outra medida reconhecida é a intervenção judicial em atividade empresarial, com cautela para evitar danos ao funcionamento da empresa, que, embora seja uma medida extrema, muitas vezes é um dos únicos mecanismos eficazes. ${ }^{22}$

19 De acordo com Marcus Vinícius Motter Borges sustenta "nos meios sub-rogatórios típicos, sempre existirá correlação; nas coerções típicas, inexiste essa correlação; e nas coerções atípicas, a afinidade, apesar de importante, não é obrigatória”. (BORGES, 2019, p. 361).

20 Essa relação é apresentada em dois exemplos por Daniel Amorim Assumpção Neves: “Interessantes exemplos são dados pela melhor doutrina: suspensão do direito do devedor de conduzir veículo automotor, inclusive com a apreensão física da $\mathrm{CNH}$, em caso de não pagamento de dívida oriunda de multas de trânsito (incluo as indenizações por acidentes ocorridos no trânsito); [...] proibição de empréstimo ou de participação em licitações a devedor que não paga o débito relativo a financiamento bancário”. (NEVES, 2016, p. 986-987).

21 STJ (1. Seção). REsp 1069810/RS. Relator: Min. Napoleão Nunes Maia Filho. Julgado em 23/10/2013, DJe $06 / 11 / 2013$.

22 A matéria foi alvo de intensa discussão durante a tramitação do Código, tanto na Câmara quanto no Senado. Teve inicialmente sua previsão estabelecida; após ganhou um disciplinamento mais específico com referência à sua excepcionalidade e ao regulamento do tema nos artigos 102 a 111 da Lei n. $\stackrel{\text { o }}{12.529}$, de 30 de novembro de 2011. Porém, na reta final, o dispositivo foi excluído. 
Merece referência, ainda, a utilização da prisão civil como meio executório atípico. Logicamente, a utilização desse meio executório deve ser a ultima ratio, devendo estar pautada em requisitos mais rigorosos ${ }^{23}$ do que os exigidos para as demais medidas. Sua aplicação deve ficar reservada às situações inadiáveis e fundadas em imperativos de elevada relevância jurídica, destinada a evitar a negativa de prestação jurisdicional em tais hipóteses. ${ }^{24}$

É possível citar outras medidas atípicas, como a proibição da participação em licitações, a retenção de passaporte, a retenção de habilitação para dirigir, proibição de participação em concursos, a restrição na utilização de cartões de crédito, o corte no fornecimento de energia elétrica, água ou gás, a prisão civil, etc. ${ }^{25}$

Uma parte das medidas executórias atípicas possui um nível elevado de gravidade diante das restrições que podem causar a direitos do executado. Um primeiro limite que deve ser lembrado é a responsabilidade patrimonial do executado, de modo que não se podem atingir outros bens jurídicos distintos do patrimônio por meio das execuções jurisdicionais.

Outra questão que não pode ser ignorada é o fato de que, em determinadas situações, as medidas executórias atípicas podem violar garantias fundamentais, como a liberdade de locomoção ou a própria dignidade humana. Todavia, somente na análise do caso concreto é possível aferir a sua adequação ao ordenamento jurídico, não havendo como imputar abstratamente nenhuma delas como ilegal ou inconstitucional.

Isso porque a grande maioria desses casos não será resolvida por meio de definições legais objetivas, mas mediante a análise de ponderação de princípios constitucionais colidentes. É preciso manter em mente que a satisfação do crédito do exequente se conecta diretamente com a garantia constitucional da inafastabilidade da jurisdição em sua dimensão de efetividade. Logo, a definição da viabilidade da medida atípica deverá considerar a interferência entre esse princípio e o que fundamenta a defesa do executado, de acordo com as premissas fáticas do caso concreto.

Vale mencionar que existem defensores da inconstitucionalidade em análise abstrata da utilização como medida executória atípica da apreensão de passaporte e da carteira nacional de habilitação, por violação ao direito à liberdade de locomoção (art. 5.․, XV), da vedação à participação em concurso ou em licitação públicas, por violação aos princípios da legalidade administrativa, do concurso público e da licitação (arts. 5. , II, 37, I, e XXI). ${ }^{26}$ Como dito, entende-se difícil a definição abstrata da inconstitucionalidade.

Outro limite à atuação do juiz na definição de ofício de meios executórios é o respeito ao autorregramento da vontade das partes e à disponibilidade da execução. Dessa forma, existindo negócio processual firmado entre as partes para a exclusão de um meio executório específico (art. 190 do CPC) ou se o exequente desistir de alguma medida executiva (art. 775 do CPC) o juiz não pode determinar essa medida com fundamento no artigo 139, IV, do CPC. Nessa hipótese, a efetividade do processo não pode ser levantada como argumento em função da disponibilidade da execução.

23 Como sugestão de parâmetros: “a determinação da prisão civil deve obedecer, pelo menos, aos seguintes requisitos: I) subsidiariedade em relação aos meios executórios típicos; II) possibilidade de cumprimento da prestação pelo destinatário da ordem; III) indispensabilidade da submissão do meio executório atípico indicado pelo juiz ao contraditório; e IV) fundamentação adequada quanto à escolha da medida; V) o conteúdo não patrimonial da obrigação; VI) o direto a ser tutelado possuir relevante maior que a liberdade de locomoção no caso concreto; VII) a excepcionalidade da medida”. (ARAGÃO, 2018, p. 107).

24 Nesse sentido Fredie Didier Jr., Leonardo Carneiro da Cunha, Paula Sarno Braga e Rafael Alexandria de Oliveira (2017, p. 130): “A prisão civil como medida atípica só deve ser utilizada em último caso, quando não foi possível alcançar a tutela específica ou o resultado prático equivalente por nenhum outro meio. É inadmissível, pelos prejuízos que é capaz de gerar, utilizá-la como primeira medida”.

25 É o que se colhe do escólio de Fernando da Fonseca Gajardoni: "Ilustrativamente, não efetuado o pagamento de dívida oriunda de multas de trânsito, e superados os expedientes tradicionais de adimplemento (penhora de dinheiro e bens), seria lícito o estabelecimento da medida coercitiva/indutiva de suspensão do direito a conduzir veículo automotor até pagamento do débito (inclusive com apreensão da CNH do devedor); [...] ou mesmo a participação do devedor em licitações (como de ordinário já acontece com pessoas jurídicas em débito tributário com o Poder Público); etc. (GAJARDONI, 2017).

26 Tramita com esse objeto a ADI n. $.0070735-42.2018 .1 .00 .0000$, da relatoria do Ministro Luiz Fux, ainda sem manifestação de cautelar ou de mérito até a data do fechamento desta edição do livro. 


\section{Conclusões}

Por tudo que fora exposto, a título de conclusão, é possível afirmar que os meios executórios atípicos são importantes para resguardar o princípio da efetividade processual, em especial em para superação de obstáculos criados pelos devedores em processos de execução de maior complexidade.

Sabe-se que o procedimento base das execuções está disciplinado na legislação no intuito de garantir ao executado certa previsibilidade da ordem procedimental. Porém, é igualmente sabido que os meios executórios típicos não são suficientes para superar todos os obstáculos criados pelos executados. Com isso, é reconhecida a atipicidade dos meios executórios como importante ferramenta de efetividade processual.

Não obstante, as áreas do processo que possuem maior maleabilidade devem ser conduzidas com base em critérios objetivos com o intuito de garantir o respeito ao devido processo legal, evitando a violação a direitos do executado. Por essa razão, a decisão que determina medidas executórias atípicas deve estar suficientemente fundamentada.

Para evitar que tal medida fique a cargo de apreciação discricionária do juiz, a decisão do juiz deve estar pautada por critérios claros e seguros que garantam que as especificidades da causa foram contempladas. Defende-se que devem ser respeitados, pelo menos, os seguintes requisitos: I) subsidiariedade em relação aos meios executórios típicos; II) possibilidade de cumprimento da prestação pelo destinatário da ordem; III) indispensabilidade da submissão do meio executório atípico indicado pelo juiz ao contraditório; IV) proporcionalidade da medida atípica.

Atendidos tais parâmetros as medidas executórias atendem à demanda por incremento de efetividade processual sem que importem em excessos ou violem direitos dos executados.

\section{Referências}

ARAGÃO, Nilsiton Rodrigues de Andrade. A utilização da prisão civil como meio executório atípico. TALAMINI, Eduardo; MINAMI, Marcos Youji (Coord.). Medidas executivas Atípicas. Salvador: JusPodivm, 2018, Págs. 93-108.

BORGES, Marcus Vinícius Motter. Medidas coercitivas atípicas nas execuções pecuniárias. São Paulo: Thomson Reuters, 2019.

ASSIS, Araken de. Manual da execução. 18. ed. São Paulo: Revista dos Tribunais, 2016.

GAJARDONI, Fernando da Fonseca. A revolução silenciosa da execução por quantia. Disponível em: http://jota.uol.com.br/a-revolucao-silenciosa-da-execucao-por-quantia. Acesso em: 22 abr. 2017.

GUERRA, Marcelo Lima. Direitos fundamentais e a proteção do credor na execução civil. São Paulo: Revista dos Tribunais, 2003.

MARINONI, Luiz Guilherme; ARENHART, Sérgio Cruz; MITIDIERO, Daniel. Novo Código de Processo Civil comentado. São Paulo: Revista dos Tribunais, 2017.

MARINONI, Luiz Guilherme. Técnica processual e tutela dos direitos. 3. ed. São Paulo: Revista dos Tribunais, 2010.

MINAMI, Marcos Youji. Breves apontamentos sobre a generalização das medidas de efetivação no CPC/2015: do processo para além da decisão. DIDIER JR., Fredie (coord.); MACÊDO, Lucas Buril de; PEIXOTO, Ravi; FREIRE, Alexandre (org.). Execução. Salvador: Jus Podivm, 2015.

MINAMI, Marcos Youji. Da vedação ao non factibile: uma introdução às medidas executivas atípicas. Salvador: JusPodivm, 2019.

NEVES, Daniel Amorim Assumpção. Medidas executivas coercitivas atípicas na execução de obrigação de pagar quantia certa - art. 139, IV, do novo CPC. Revista de Processo, São Paulo, v. 265, 2017. 
NEVES, Daniel Amorim Assumpção. Manual de direito processual civil. 8. ed. Salvador: JusPodium, 2016. MOREIRA, José Carlos Barbosa. Por um processo socialmente efetivo. Revista de Processo, São Paulo, v. 27, n. 105, jan./mar. 2002.

ZANETI JR., Hermes. Comentários ao código de processo civil: artigos 824 ao 925. São Paulo: Revista dos Tribunais, 2016. 